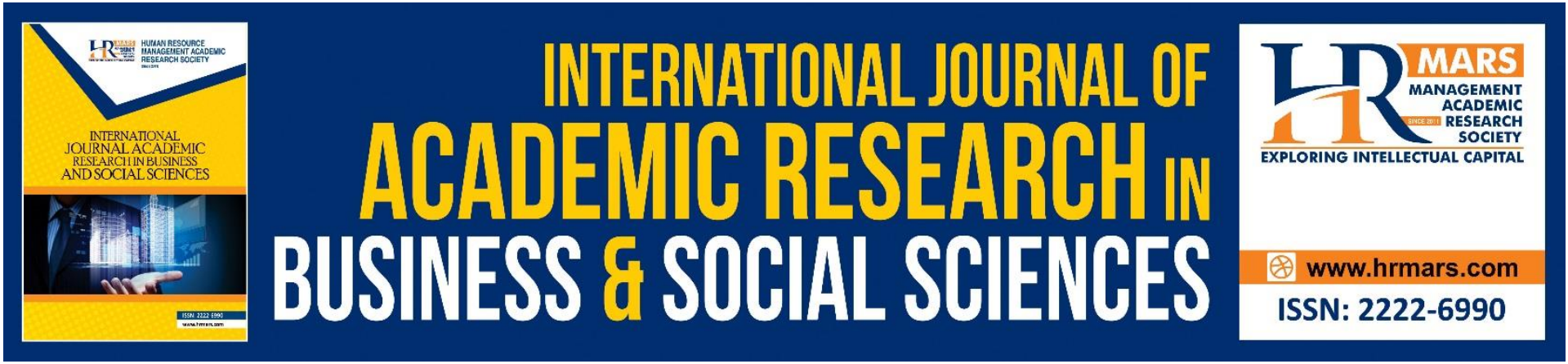

\title{
Al-Nabr: Analisis of Quranic Recitation through Spectrographic Method
}

\section{Azizul Hassan \& Mohd Faiz Mohd Yasin}

To Link this Article: http://dx.doi.org/10.6007/IJARBSS/v11-i12/11859

DOI:10.6007/IJARBSS/v11-i12/11859

Received: 10 October 2021, Revised: 12 November 2021, Accepted: 25 November 2021

Published Online: 19 December 2021

In-Text Citation: (Hassan \& Yasin, 2021)

To Cite this Article: Hassan, A., \& Yasin, M. F. M. (2021). Al-Nabr: Analisis of Quranic Recitation through Spectrographic Method. International Journal of Academic Research in Business and Social Sciences, 11(12), 1242-1033.

\section{Copyright: (c) 2021 The Author(s)}

Published by Human Resource Management Academic Research Society (www.hrmars.com)

This article is published under the Creative Commons Attribution (CC BY 4.0) license. Anyone may reproduce, distribute, translate and create derivative works of this article (for both commercial and non0-commercial purposes), subject to full attribution to the original publication and authors. The full terms of this license may be seen at: http://creativecommons.org/licences/by/4.0/legalcode

Vol. 11, No. 12, 2021, Pg. $1024-1033$

Full Terms \& Conditions of access and use can be found at http://hrmars.com/index.php/pages/detail/publication-ethics 


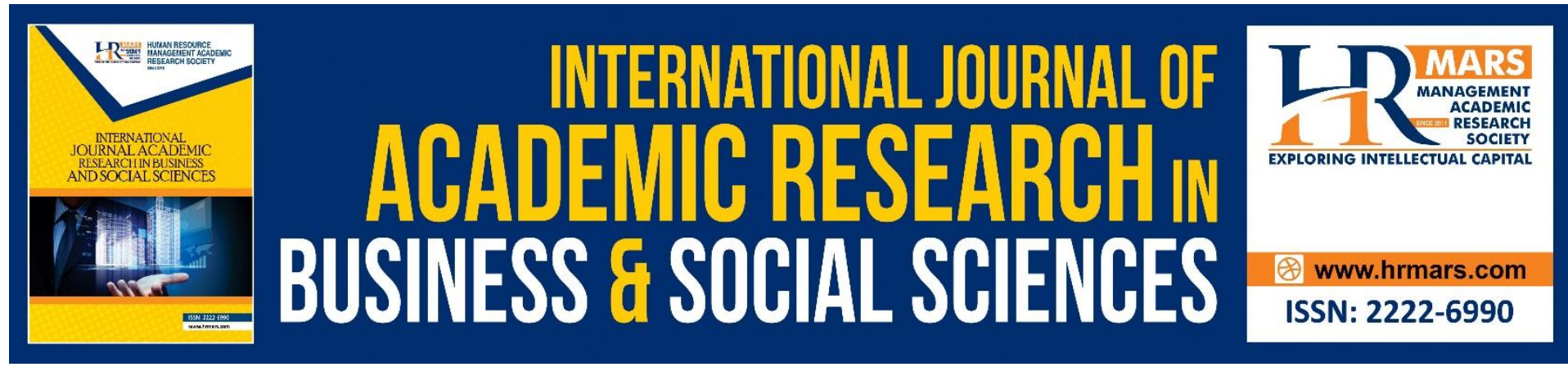

\title{
Al-Nabr: Analisis of Quranic Recitation through Spectrographic Method
}

\author{
Azizul Hassan ${ }^{1} \&$ Mohd Faiz Mohd Yasin ${ }^{2}$ \\ ${ }^{1}$ Faculty Islamic Contemporary Studies, Universiti Sultan Zainal Abidin, ${ }^{2}$ Centre of \\ Fundamental and Continuing Studies, University Malaysia Terengganu \\ Email: azizulhassan@unisza.edu.my
}

\begin{abstract}
Al-Nabr is an element in voice intonation related to Quranic recitation that holds implication to the meaning of word recited. Scholars of vocal phonetics and qurra (reciters) have explained on subject of al-nabr through respective fields' perspective. However, incompleteness of recitation by ignoring al-nabr aspect has been connected to recitation error although there is no clear argument on this subject except several general discussions on it. Therefore, to validify the existence of al-nabr recitation dan its practice among reciters then analysis of recitation through spectrographic method was performed on recordings of recitation from authorised reciters. Analysis found that al-nabr recitation is not a practice among the reciters and as a whole explains their practical recitation practice on this al-nabr.
\end{abstract}

\section{Introduction}

Arguments on al-nabr among reciters is anew subject included in books of Tajwid knowledge. Signs on al-nabr recitation practice is not so widespread among past reciters. In fact, it is a discussion that becomes a focus among scholars in Arabic phonetics fiels only. However, recently al-nabr argument begins to be detailed by contemporary fogures of reciters as scholars of Arabic linguistics begin to connect al-nabr element to Quranic recitation.

In phonetics study, Arabic scholars have surpassed western scholars through Quranic phonetics study. Al-Quran al-Karim which has to be recited with certain recitation methods is the main source of phonetics study in Arabic language. Research on properties of vocal discipline named phonetics study has begun to grow in Arabic language through arrival of Islam bringing along the holy book al-Quran al-Karim (Rahman, 2002). Phonetics study is divided into articulatory phonetics, auditory phonetics and acoustics phonetics. Articulatory phonetics discusses on speaking skills using organs and articulatory zones. Auditory phonetics meanwhile describes listening skills to produced sounds. While for acoustics phonetics, it studies transmission of sounds produced by articulatory organs (Zahid \& Omar, 2006). Acoustics phonetics involve three physical features of lingual speech which are pitch, intensity and length (Jalaluddin, 2007).

Scholars of Arabic linguistics (Fikri, 1995; Basir, 2000) have listed suprasegmental aspects that should be emphasised in Arabic speech: 
1- Pronunciation of letter, syllable, compound word and sound clearly.

2- Stress (firm or soft).

3- Mora or mad (long or short).

4- Pause (its usage is to separate linguistics elements that can bring change in meaning)

5- Intonation (raising or lowering of pitch)

Voice stress (al-nabr) is one of suprasegmental aspects that should be attended in Arabic speaking skills. According to al-Mu'jam Al-'Arabiy Al-'Assasiy (1999) al-nabr literally means a syllable in word which is the most prominent in speech. According to Ladefoged (1993); alKhuli (1990); Abdullah (2004) al-nabr is stress of the more prominent syllable compared to other syllables in Arabic word pronunciation. The prominence meant is the higher and longer voice strength and also the one most attractive to the listener compared to other syllables in the word. The stressed word also shows higher pitch making it clearer if compared to other syllables in the word. Roach (2009) stated that every stressed syllable in word owns a similar feature which is more prominent compared to other syllables. Prominent voice stress (al-nabr) can be measured through several methods, among them are intensity, vowel length, pitch and vowel quality.

Al-Quran is words of Allah S.W.T which is a miracle descended upon Prophet Muhammad S.A.W through intermediary of angel Gabriel A.S. It is written on several mashafs quoted and arranged from authentic narrations and its recitation is considered a worship ritual. Based on unique and 'ijaz (إعجاز) properties of al-Quran, then it is needed for everyone to master several knowledge to perfect the knowledge of Quranic recitation revealed by Allah S.W.T. Al-Quran as known by Muslim community is the greatest miracle inherited from Prophet Muhammad S.A.W. Miracles of al-Quran a re so wide encompassing all aspects, including linguistics and phonetics aspect that should be unveiled and discovered.

Therefore, qurra have contradicted in views on this subject by three groups which are the one that permits it by most of contemporary qurra', the one that denies it such as Syeikh AlSahhabiy and the one in moderate between those two such as Syeikh Ibrahim al-Akhdar (Ahmad, 230:2017).

\section{Issue \& Problem}

To qurra' permitting it either involving all words or some of them, they believe that reciting without al-nabr is included in category of hidden error (lahn khafiy) with ruling of makruh (alAttar: 207:2008). As it is connected to one of Quranic recitation forms, then an experimental examination should be performed by analysing qurra's recitations through spectrogram to investigate the extend of their recitation practice regarding this al-nabr.

\section{Definition of al-Nabr}

Al-Nabr in Kamus Besar Arab-Melayu Dewan (2006 : 2287) is defined as raising or loudening of voice or putting of hamzah at its end or pressure (pressure producing loud voice).

\section{Methodology}

This study generally aimed to explore al-abr recitation among qurra' to benefited alongside recent technology. Specifically, this study aimed to analyse al-nabr recitation among qurra' in 
Quranic recitation through spectrogram application by examining voice stress among qurra' through spectrogram application. Analysis performed was based on recordings of Quranic recitation by four authorised Quranic figures who were Syeikh Dr. Ayman Suwayd, Syeikh Dr. Ali al-Huzaifiy, Syeikh Mahmud Khalil al-Husariy dan Syeikh Mahmud Ali al-Banna. The recitations were specified to the word in qurra's attention such as (وقالا الحمد) verse 15 surah al-Naml and (ذاقا الشجرة) verse 22 surah al-A'raf.

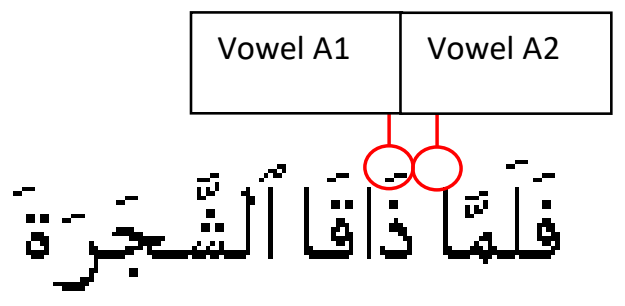

Figure 1 Verse 22 surah al-A'raf (first sample)

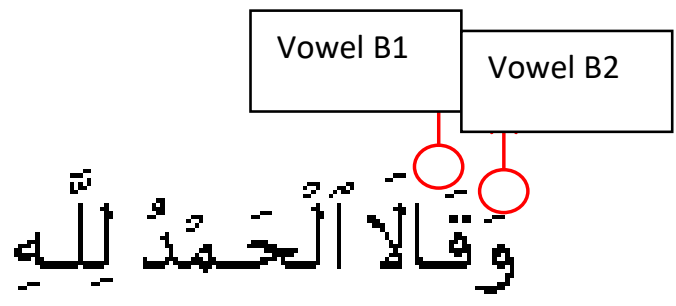

Figure 2 Verse 15 surah al-Naml (second sample)

The intensities of these samples were measured at vowels which represent the formant area as in Figure 1 and Figure 2, as it is the peak of wave spectrum in voice signal (Subali et al., 2015). The spectrogram used was from Praat software (Version 5.3.56; Boersma and Weenink, 2013). The settings for spectrogram in this analysis are: Dynamic range of 40 Decibles, Window length of 0.025 seconds and View range of 0-5000 Hertz. The samples were opened and analysed from intensity aspect through 'Intensity' function in Praat. The patterns of intensity line for the first and second vowel were compared. Then, the average intensity value for vowel area was compared between the first and second vowel. 


\section{Analysis and Findings}

The followings are spectrographic displays for both samples from the four qurra'.

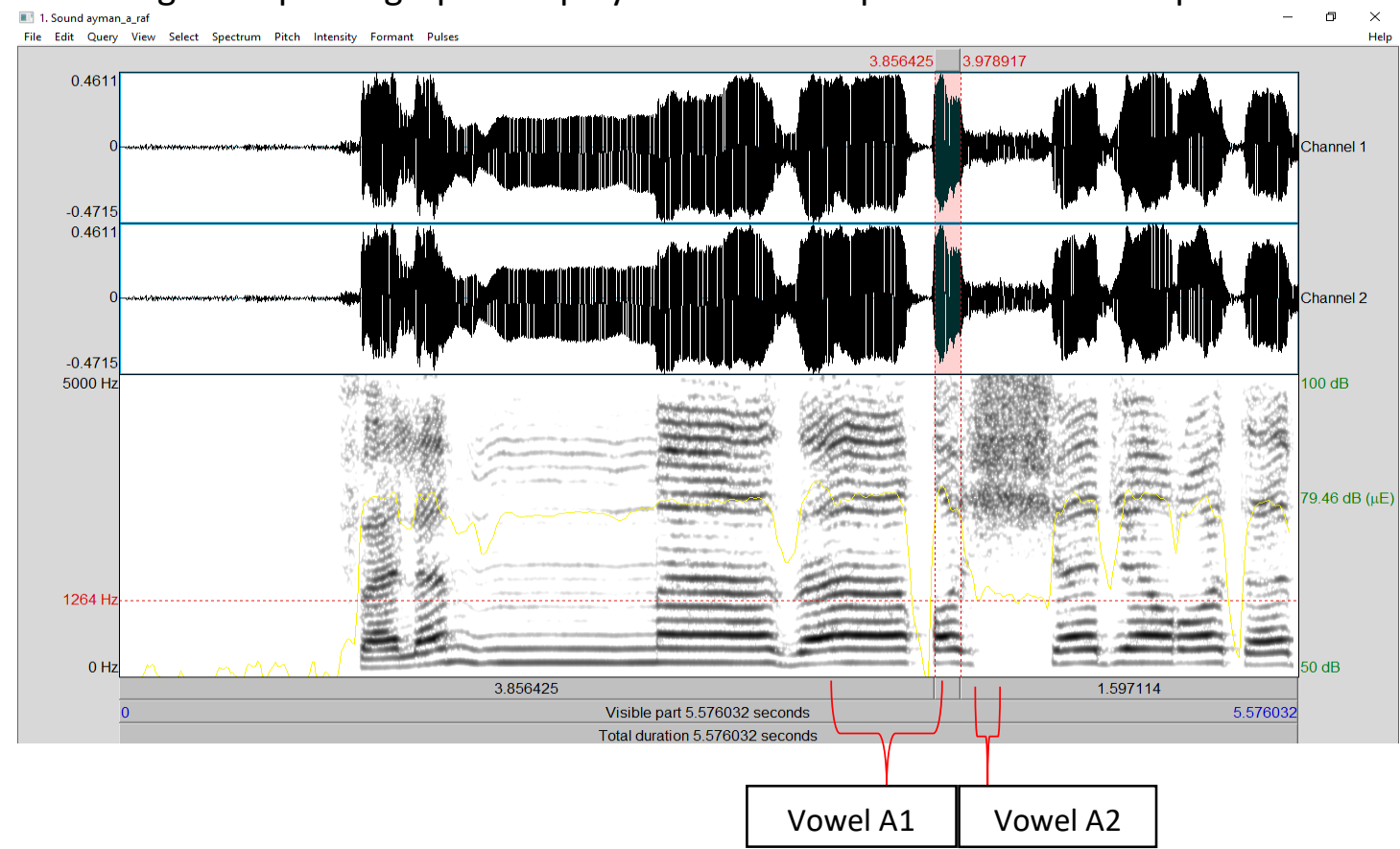

Figure 1a Spectrographic display for first sample by Dr. Ayman Suwayd

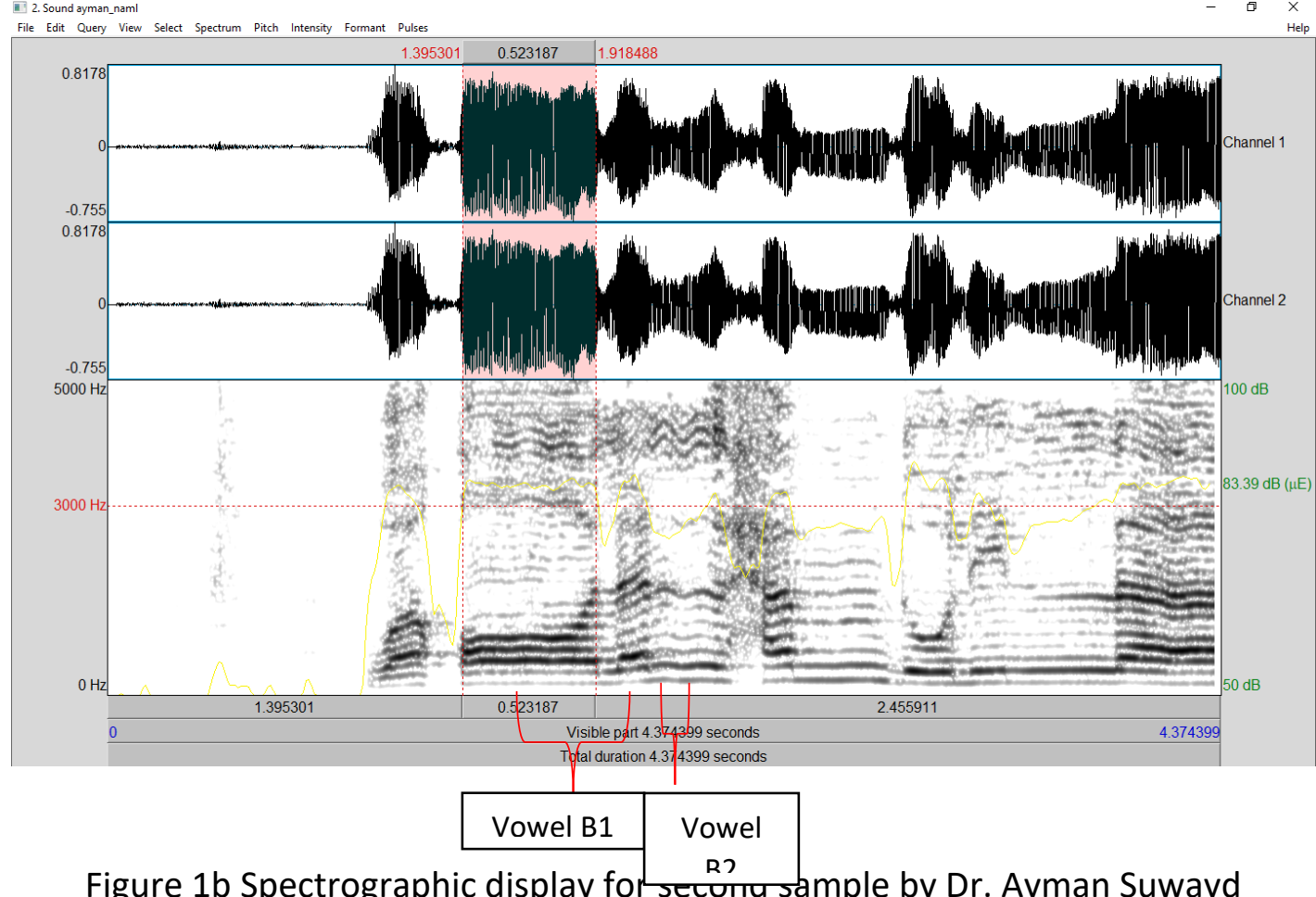

Figure $1 b$ Spectrographic display forsecuriu sample by Dr. Ayman Suwayd 


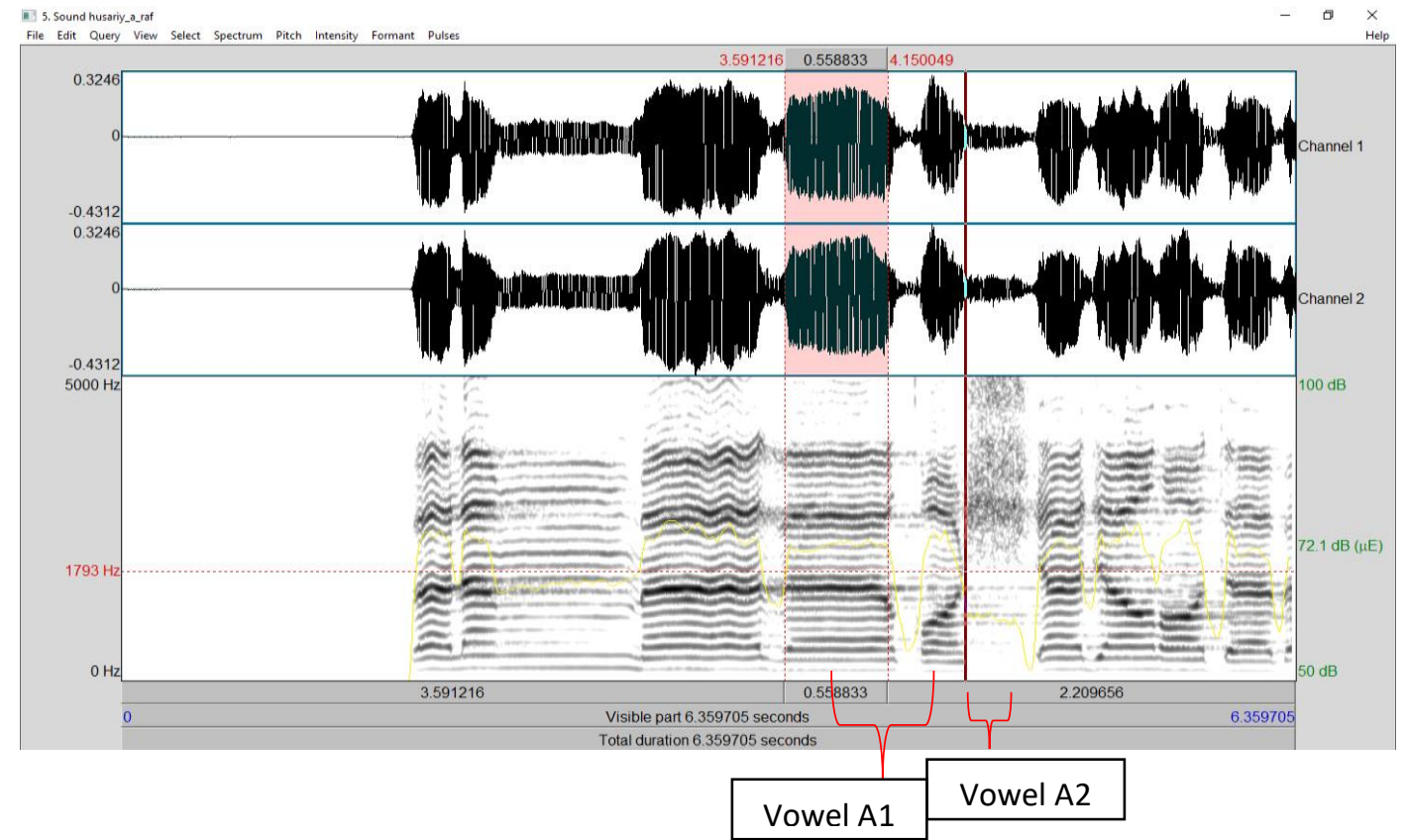

Figure 2a Spectrographic display for first sample by Sheikh Mahmud Khalil al-Husariy

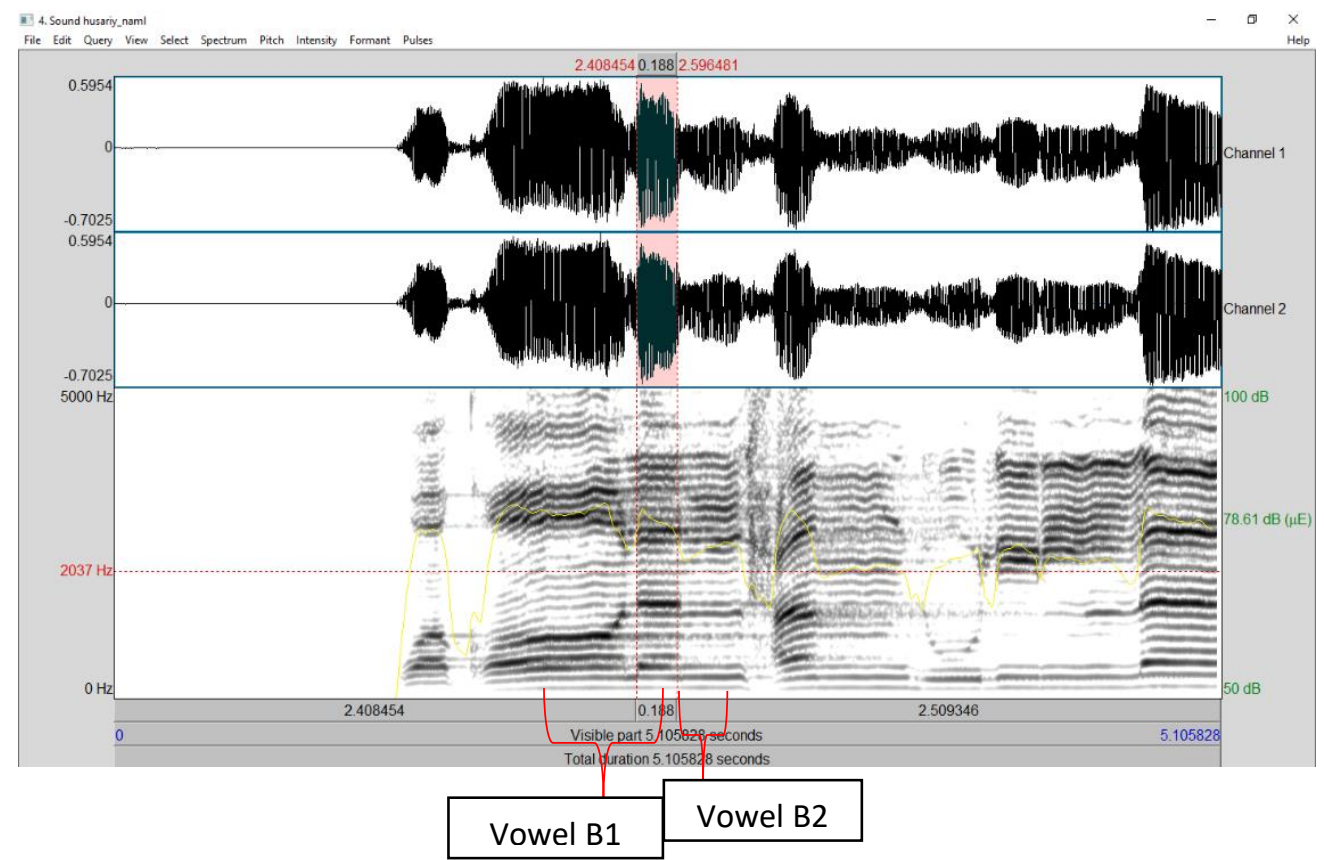

Figure $2 \mathrm{~b}$ Spectrographic display for second sample by Sheikh Mahmud Khalil al-Husariy 


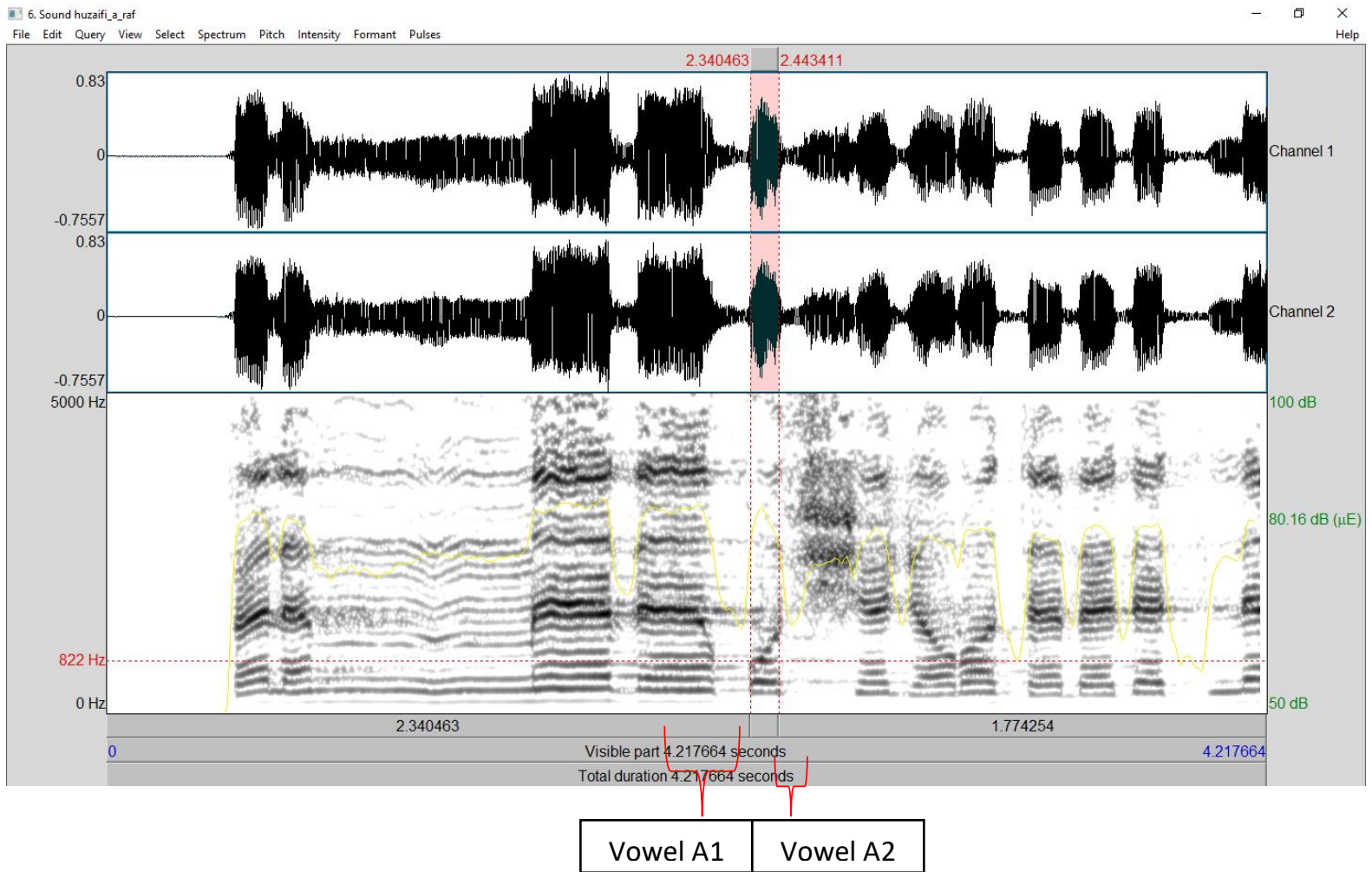

Figure 3a Spectrographic display for second sample by Sheikh Sheikh Dr. Ali al-Huzaifiy

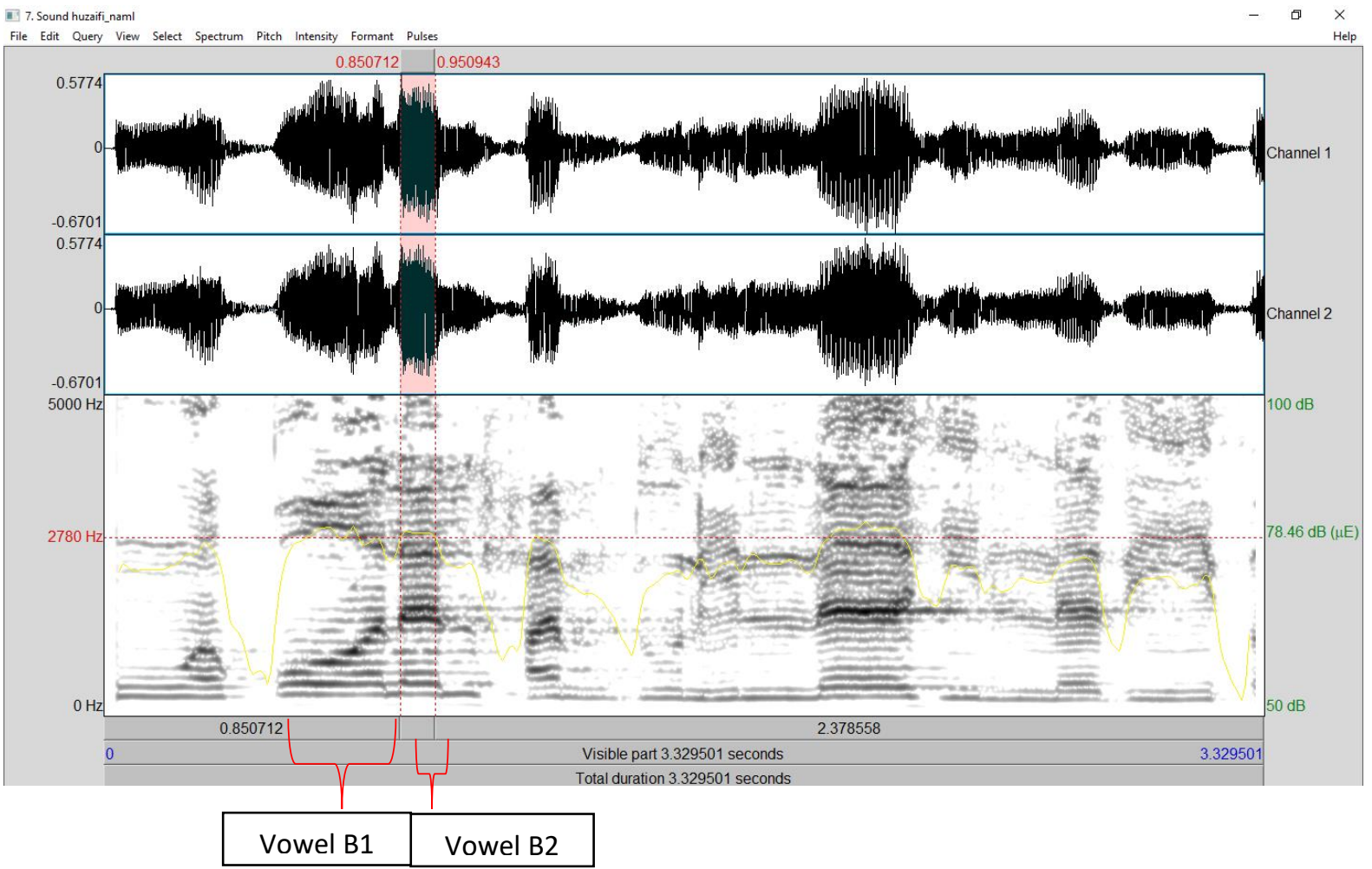

Figure 3b Spectrographic display for second sample by Sheikh Dr. Ali al-Huzaifiy 


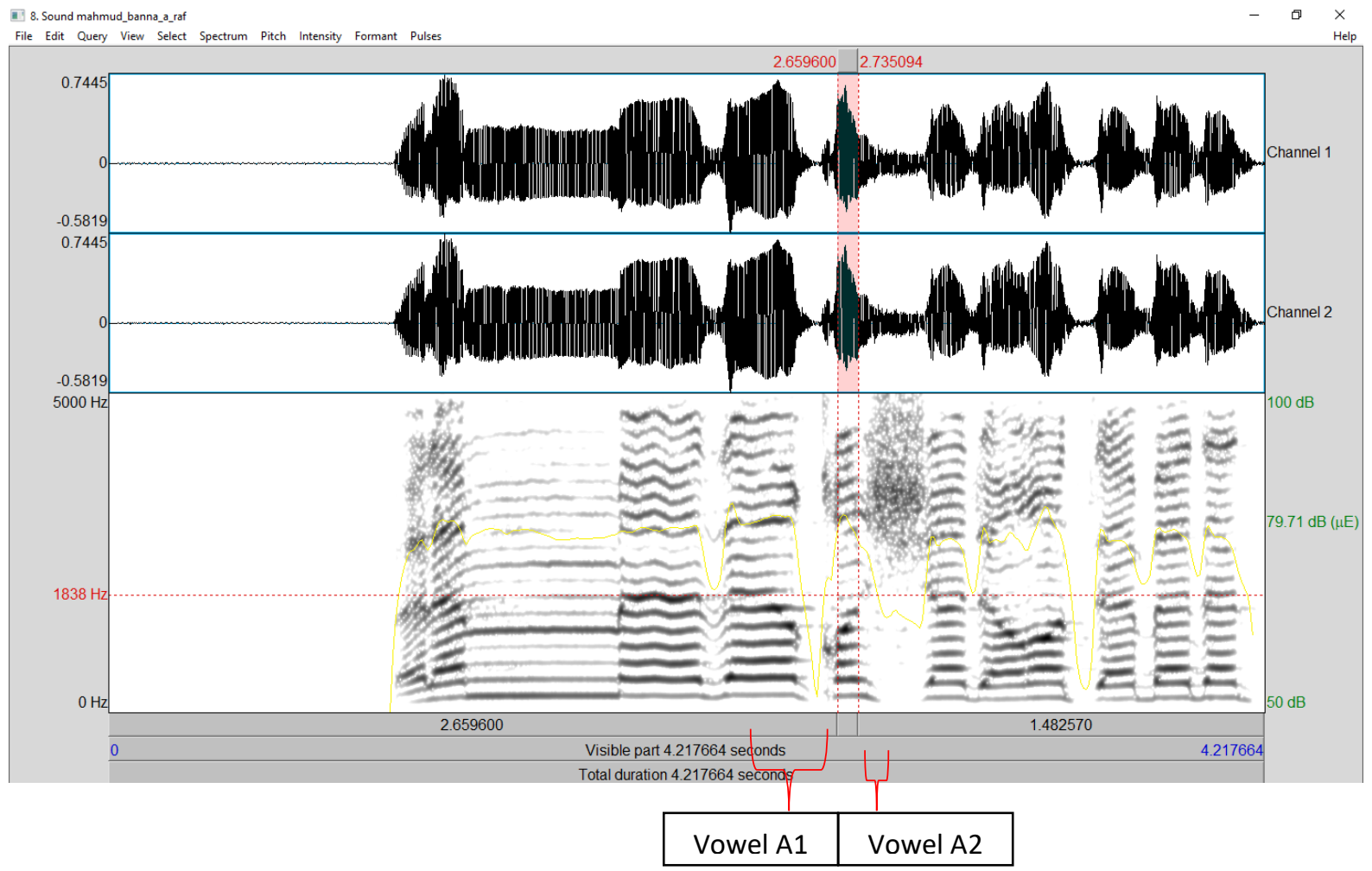

Figure 4a Spectrographic display for first sample by Sheikh Mahmud al-Banna

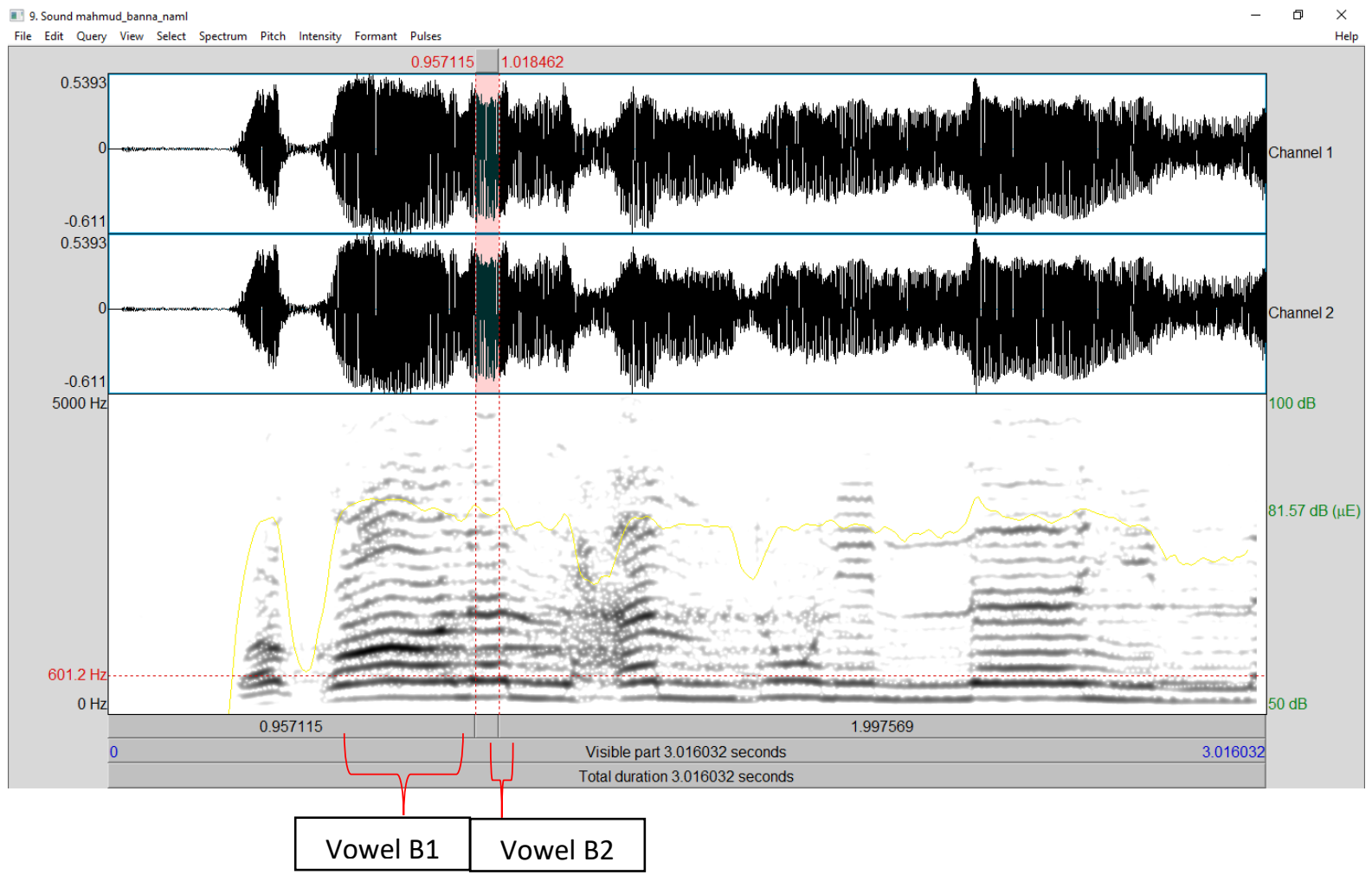

Figure 4b Spectrographic display for second sample by Sheikh Mahmud al-Banna 
In the spectrographic displays, the intensity level is indicated by the yellow horizontal line. From the data, it is generally observed that the intensity line for the second vowel is not always prominently higher than for the first vowel. Meanwhile, the intensity values for the vowels are visualised in Table 1 in details.

Table 1 Average intensity value of vowels for qurra'

\begin{tabular}{|l|c|c|c|c|}
\hline \multirow{2}{*}{ Qari } & \multicolumn{3}{|c|}{ Average intensity value of vowel } \\
\cline { 2 - 5 } & A1 & A2 & B1 & B2 \\
\hline $\begin{array}{l}\text { Dr. Ayman } \\
\text { Suwayd }\end{array}$ & 80.23 & 79.46 & 83.39 & 83.17 \\
\hline $\begin{array}{l}\text { Sheikh Mahmud } \\
\text { Khalil al-Husariy }\end{array}$ & 72.13 & 73.48 & 79.70 & 78.61 \\
\hline $\begin{array}{l}\text { Sheikh Dr. Ali al- } \\
\text { Huzaifiy }\end{array}$ & 81.70 & 80.16 & 77.82 & 78.46 \\
\hline $\begin{array}{l}\text { Sheikh Mahmud } \\
\text { al-Banna }\end{array}$ & 80.58 & 79.71 & 82.88 & 81.59 \\
\hline
\end{tabular}

From Table 1, it is seen that for all pairs of vowels, the intensity value for first vowel is always larger than the second one. Only for pair A1 and A2 for Sheikh Mahmud Khalil al-Husariy and pair B1 and B2 for Sheikh Dr. Ali al-Huzaifiy show larger intensity value for second syllable compared to the first one. Generally, it can be concluded that there is no consistent practice of al-nabr among all qurra' involved in this study. If al-nabr is consistently practised, the intensity value for the second value must always be higher than the first one.

\section{Conclusion}

From the analysis, it is observed that the intensity line and intensity value for the second syllable is not always higher than for the first syllable. This shows that al-nabr is not a common practice among the qurra'. Should it be compulsory, the second syllable must always show higher intensity line and value. But it is not the case. Therefore, it should not be a dispute and worrisome among Muslim community of not practising al-nabr in Quranic recitation.

\section{References}

Said, S. (2013). Analisis Al-Nabr Dalam Surah An-Nisa. Fakulti Bahasa Dan Linguistik University Malaya Kuala Lumpur.

Mu'izzuddin, M. (2020). Analisis Fonologi Bahasa Arab :Tinjauan Linguistik Modern. Al Qalam, [S.I.], 19 (93), p. 67-90

Zahroh, H., Fitriani, I. N. (2020). Dentifikasi Posisi An-Nabr Dalam Kartun Muhsin Wa Mahasin Episode At-Tafakhur. Proceeding Seminar Nasional Bahasa Arab Mahasiswa. 5(2021).

Bakar, K. A. (2018). Tekanan (Al-Nabr) Perkataan Arab Sebagai Bahasa Asing Dalam Kalangan Penutur Melayu. GEMA Online ${ }^{\circledR}$ Journal of Language Studies. 18(1). 87-105.

Ramli, N. A., Mezah, C. R., Thai, Y. N. (2016). Penguasaan Pelajar Melayu Terhadap Tekanan Suara Menyebut Perkataan Arab Dari Sudut Intensiti. Jurnal Kemanusiaan, 14(1) 110 123 .

Subali, M., Andriansyah, M., \& Sinambela, C. (2015). Analisis Frekuensi Dasar dan Frekuensi Formant dari Fonem Huruf Hija'iyyat untuk Pengucapan Makhraj dengan Metode DTW. 
Proceeding PESAT (Psikologi, Ekonomi, Sastra, Arsitektur \&Teknik Sipil) Universitas Gunadarma, Depok, 20-21st October 2015.

Boersma, P., \& Weenink, D. (2013). Praat: Doing Phonetics by Computer (Versi 5.3.56).

Mokhtar, W. K. A. W., Ibrahim, A., \& Embong, A. H. (2018). Al-'Aqīdat Al-Ṣaḥịhat as the Essential Element of Worldview of Development Integrity and Accountability. International Journal Of Academic Research In Business And Social Sciences, 8(11), 328337.

Ibrahim, A., Mokhtar, W. K. A. W., Ali, S., \& Simin, M. H. A. (2017). Effect of transformational principal leadership style on teachers commitments and school achievement. International Journal of Academic Research in Business and Social Sciences, 7(5), 518527 